\title{
Observations on carnivorous feeding in Antarctic calanoid copepods
}

\author{
Cornelia Metz*, Sigrid B. Schnack-Schiel
}

Alfred-Wegener-Institut für Polar- und Meeresforschung, Postfach 1201 61, D-27515 Bremerhaven, Germany

\begin{abstract}
Feeding experiments were carried out on board RV 'Polarstern' in February 1994 in the Bellingshausen Sea, Antarctica, to investigate carnivorous feeding in dominant large calanoid copepods. Adult females of the winter diapause species Calanoides acutus and Rhincalanus gigas did not feed on females of the poecilostomatoid copepod Oncaea curvata. In contrast, adult Calanus propinquus and Metridia gerlachei females, which remain active during winter, fed on $O$. curvata females. However, no feeding on $O$. curvata females by juvenile $M$. gerlachei was observed. Additional food sources, such as detritus and small protozooplankton, are suggested, because the amount of animal prey ingested is not sufficient to meet the energy demands of the investigated species.
\end{abstract}

KEY WORDS: Copepod Carnivorous feeding Antarctic

\section{INTRODUCTION}

Temperate and polar seas are characterised by a distinct seasonal pattern of primary production, with a corresponding food limitation for herbivorous zooplankton. The life cycles of zooplankton are affected by the scarcity of food during winter months. Low standing phytoplankton stocks probably mean that herbivorous zooplankton are unable to meet metabolic demands solely on an algal diet, and presumably eat other food such as proto- and metazooplankton (Parsons \& LeBrasseur 1970). Some copepod species are known to reduce their metabolic activities, overwintering in a dormant state (Smith \& Schnack-Schiel 1990, Conover \& Huntley 1991). Laboratory studies have shown that herbivorous Calanus species and Rhincalanus nasutus can ingest copepod eggs, copepod nauplii, barnacles and the brine shrimp Artemia (Conover 1966, Mullin \& Brooks 1967, Corner et al. 1974, 1976, Landry 1981). These species can switch to animal prey, and it is possible that they survive periods of low phytoplankton stocks by feeding carnivorously.

In the Southern Ocean 4 calanoid copepods dominate the zooplankton biomass in many regions: Cala-

·E-mail: cmetz@awi-bremerhaven.de noides acutus, Calanus propinquus, Rhincalanus gigas and Metridia gerlachei (Hopkins 1985a, 1987. Hopkins \& Torres 1988, Boysen-Ennen et al. 1991, Hopkins et al. 1993a, b). Gut content analyses indicate that all 4 species are predominantly small-particle grazers feeding on phytoplankton and protozoans (Hopkins 1985b, 1987, Hopkins \& Torres 1989, Hopkins et al. $1993 a, b)$. On the other hand, different life strategies in response to the distinct seasonality of phytoplankton stocks have been suggested (Schnack-Schiel \& Hagen 1995). The herbivorous C. acutus is a strong ontogenetic seasonal migrant which overwinters in a resting stage at depth. It accumulates large lipid stores containing wax esters (Marin 1988, Atkinson 1991. Schnack-Schiel et al. 1991, Bathmann et al. 1993, Hagen et al. 1993, Schnack-Schiel \& Hagen 1995). Part of the $C$. propinquus population remains active during winter in the upper water layers, the rest migrating to deeper waters (Marin 1988, Bathmann et al. 1993, Hopkins et al. 1993a). C. propinquus stores lipids in form of triacylglycerols, indicating a more opportunistic feeding mode (Schnack-Schiel et al. 1991, Hagen et al. 1993). Information about $R$. gigas is less clear: Hopkins et al. (1993b) described $R$. gigas as exclusively herbivorous, although deviating lipid compositions led Graeve et al. (1994) to suggest that $R$. gigas is not purely a herbivore. Gut content analyses suggest 
Table 1 Mean copepod lengths and carbon contents. Carbon values are estimated from dry weights given in the literature (see 'Methods')

\begin{tabular}{|lcc|}
\hline Species & $\begin{array}{c}\text { Total length } \\
(\mathrm{mm})\end{array}$ & $\begin{array}{c}\text { Carbon content } \\
(\mu \mathrm{g})\end{array}$ \\
\hline Calanoides acutus female & 4.9 & 275 \\
Calanus propinquis female & 5.1 & 490 \\
Rhincalanus gigas female & 7.8 & 405 \\
Metridia gerlachei female & 3.7 & 130 \\
M. gerlachei Cill-CV & 1.7 & 20 \\
Oncaea curvata female & 0.65 & 5 \\
Oncaea parila female & 0.67 & 5 \\
\hline
\end{tabular}

active feeding of $R$. gigas in May (Marin \& SchnackSchiel 1993), but not in June to August (Hopkins et al. 1993b). $R$. gigas underwent winter diapause in the mesopelagic zone in the southern Scotia Sea (Hopkins et al. 1993a). Feeding experiments and analyses of lipid and fatty acid/alcohol compositions indicate that M. gerlachei is an omnivorous species (Huntley \& Escritor 1992, Graeve et al. 1994). Hopkins et al. (1993a) found food in the guts of $M$. gerlachei in winter. This in conjunction with the low carbon:nitrogen ratios (Schnack 1985, Atkinson \& Shreeve 1995) and the moderate lipid reserves (Schnack-Schiel \& Hagen 1995) also indicates that $M$. gerlachei remains active during winter.

Small copepods of the families Oithonidae and Oncaeidae numerically dominate in the Southern Ocean throughout the year (Hopkins 1985a, Schnack et al. 1985a, Fransz 1988, Hopkins \& Torres 1988, Conover \& Huntley 1991, Schnack-Schiel unpubl.). The dominant species Oncaea curvata was therefore used as representative motile prey. However, during winter females are dispersed throughout the water column, whereas in summer they are concentrated between $300 \mathrm{~m}$ and the surface (Metz 1995). The aim of this study was to determine whether the 4 dominant Antarctic calanoid copepods can switch to carnivory and prey on

Table 2. Summary of predation experiments. Experimental set up. ingestion rates $I_{n}$ ( $\mathrm{n}_{\text {Oncaed }}$ ingested copepod $\left.{ }^{-1} \mathrm{~d}^{-1}\right)$ and $I_{C}\left(\mu \mathrm{g} C_{\text {oncaed }}\right.$ ingested copepod ${ }^{-1} \mathrm{~d}^{-1}$ ) and carbon uptake (\% of body carbon $\mathrm{d}^{-1}$ )

\begin{tabular}{|c|c|c|c|c|c|}
\hline Predator species & $n$ dish $^{-1}$ & Prey species & $I_{\mathrm{n}}$ & $I_{c}$ & Cuptake \\
\hline Calanus propinquus & 5 & Oncaea curvata & 2.4 & 12.0 & 2.5 \\
\hline females & 5 & females & 2.7 & 13.3 & 2.7 \\
\hline \multirow{4}{*}{$\begin{array}{l}\text { Metridia gerlachei } \\
\text { females }\end{array}$} & 5 & O curvata & 1.4 & 7.0 & 5.4 \\
\hline & 10 & females & 1.2 & 6.0 & 4.6 \\
\hline & 10 & & 1.0 & 5.0 & 3.9 \\
\hline & 8 & $\begin{array}{l}\text { Oncaea parila } \\
\text { females }\end{array}$ & 1.3 & 6.7 & 5.1 \\
\hline
\end{tabular}

O. curvata, thereby taking advantage of the high number of this species in the water column during winter when phytoplankton is scarce.

\section{METHODS}

Feeding experiments were conducted on board RV 'Polarstern' during February 1994 in the central Bellingshausen Sea, Antarctica. Copepods were collected at several stations with a Bongo net of $100 \mu \mathrm{m}$ mesh size hauled vertically in the upper $500 \mathrm{~m}$. They were acclimated to experimental conditions for several days. All experiments were run at $0^{\circ} \mathrm{C}$ in continuous dim light. The experimental glass dishes contained $200 \mathrm{ml}$ seawater $(0.2 \mu \mathrm{m}$ filtered), and 15 females of Oncaea curvata or, in one experiment, Oncaea parila (see Table 2). Into these dishes 5 to 10 females of Calanoides acutus, Calanus propinquus, Rhincalanus gigas and Metridia gerlachei, or copepodite stages III to $\mathrm{V}$ of $M$. gerlachei were transferred, respectively, The experiments were run with 2 to 3 replicates. The number of Oncaea spp. was checked every 3 h over a period of $24 \mathrm{~h}$ and the behaviour of the different species was observed. To calculate the carbon content of the species (Table 1), and carbon uptake in \% of body carbon (Table 2), the copepod dry weight values published by Mizdalski (1988), Conover \& Huntley (1991) and Huntley \& Escritor (1992) were used. A body carbon content of $45 \%$ was assumed (Conover \& Huntley 1991).

\section{RESULTS AND DISCUSSION}

Calanoides acutus and Rhincalanus gigas females as well as juvenile Metridia gerlachei did not feed on Oncaea spp., and no reaction towards the copepod prey was observed. In contrast, Calanus propinquus and $M$. gerlachei females fed on Oncaea spp., the number of which decreased continuously over time (Fig, 1). All 4 species were trophically active. This was proved by grazing experiments, carried out at the same time with natural phytoplankton suspensions as food (Schnack-Schiel unpubl.). Hopkins et al. (1993b) also described C. acutus and $R$. gigas as being purely herbivorous, whereas $C$. propinquus and $M$. gerlachei guts contained phytoplankton, proto-and metazooplankton in all seasons (Hopkins 1985b, 1987, Hopkins \& Torres 1988, Hopkins et al. $1993 \mathrm{a}, \mathrm{b}$ ). Interestingly the latter species had a significantly larger zooplankton component in their diet in the 
(a)

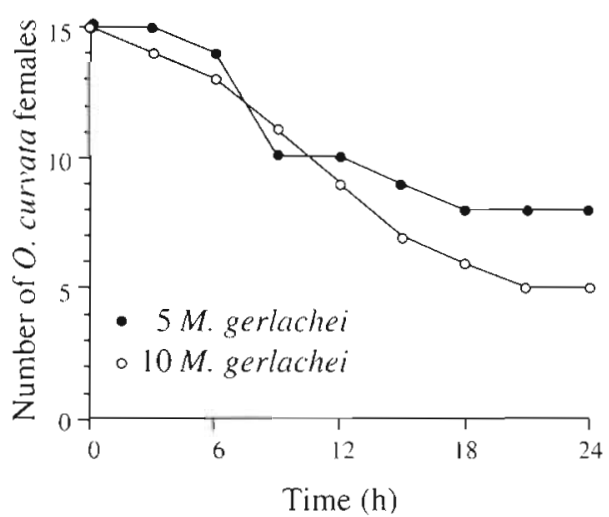

(b)

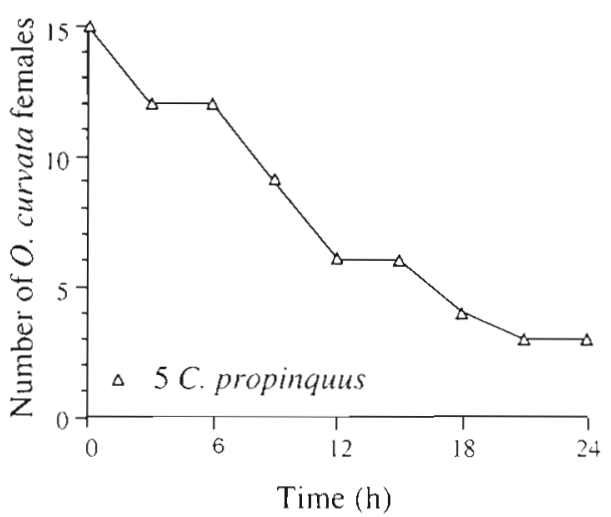

Fig. 1. Time course of example feeding experiments. Graphs show decrease of the number of Oncaea curvata over time in experimental dishes containing (a) Metridia gerlachei females or (b) Calanus propinquus females

pack ice compared to open waters (Hopkins et al 1993a). Additionally, crustacean remains, in addition to phytoplankton, have been found in the faecal pellets of $C$. propinquus in the pack ice (Atkinson \& Shreeve 1995). C. propinquus and M. gerlachei actively selected motile food (ciliates and flagellates), in contrast to $C$. acutus and $R$. gigas which were unselective feeders (cited in Atkinson \& Shreeve 1995).

The behaviour of Metridia gerlachei and Calanus propinquus females detecting and responding to copepod prey was remarkably different. M. gerlachei swam steadily, detecting their prey at a distance of about $1 \mathrm{~mm}$. After the encounter they always displayed a complex behaviour (Fig. 2a): They stopped 1 to 2 body lengths behind the Oncaea spp., turned around and passed it again. This was repeated 1 or 2 more times, and the prey was then grabbed. It seemed that this facilitated the precise locating of the Oncaea spp. Once it was detected it never escaped. C. propinquus grabbed their prey the first time they passed it (Fig. 2b). In contrast to $M$. gerlachei, C. propinquus occasionally missed the Oncaea spp. or lost them

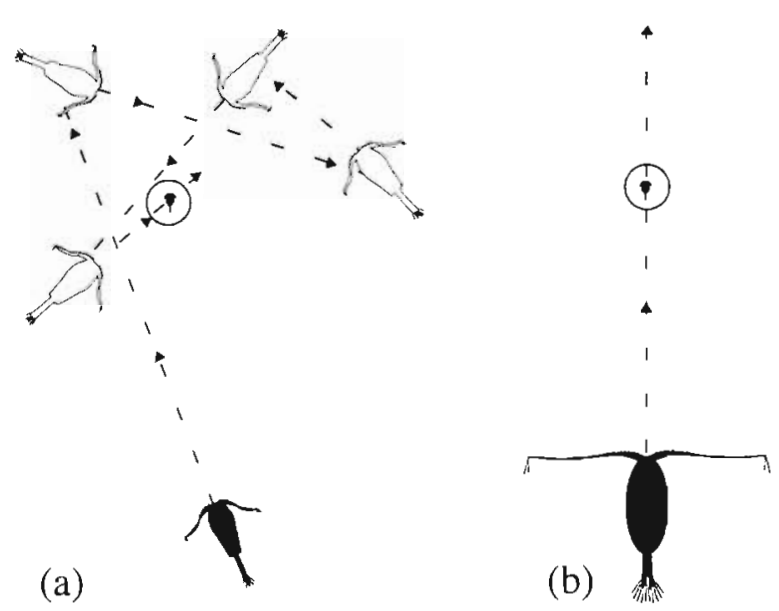

Fig. 2. Sketch of the feeding behaviours of (a) Metridia gerlachei and (b) Calanus propinquus catching Oncaea curvata (marked with a circle)

shortly after the attack. Their behaviour resembled that of Calanus hyperboreus described by Conover (1966). The feeding behaviour of C. hyperboreus depended on whether the prey was actively swimming or not: a moving nauplius was apparently sensed by $C$. hyperboreus at a few millimeters, whereas large nonmotile food particles were only detected and captured if contact was made by the feeding appendages. Typically, Oncaea curvata remained stationary for long periods of time, jumping seldom even when a predator was very close. This might be a strategy to avoid hydrodynamic disturbances which could be sensed by predators (Paffenhöfer 1988). Therefore, C. propinquus responded to $O$. curvata females as $C$. hyperboreus did to non-motile food particles. The behaviour of Metridia gerlachei, however, indicated that this species was able to sense floating prey from a distance.

Few remains such as Oncaea spp. legs or abdomens were found, and there was no evidence of the calanoids sucking out the contents of large prey as described by Cushing (1955). As so few of the captured Oncaea spp. were only partly consumed, it is most likely that calanoids chew their larger prey and retain and ingest all pieces. This was occasionally observed in Metridia gerlachei during the experiments

Daily rations depend on the size of grazers and on the size, shape and concentration of the food supply (Parsons et al. 1969, Paffenhöfer 1971, Schnack 1983b, Atkinson 1994). In the Southern Ocean most daily ration values of large calanoid species range between $<1$ and $20 \%$ of their body carbon when feeding on natural occurring phytoplankton concentrations of 0.1 to $2 \mu \mathrm{g} \mathrm{chl} \mathrm{a} \mathrm{l}^{-1}$ (Schnack 1985, Atkinson et al. 1992, Bathmann et al. 1993, Drits et al. 1993, Atkinson 1994). Feeding rates in the experiments with Oncaea spp 
females were also in this range. Calanus propinquus ingested 12 to $13 \mu \mathrm{g} \mathrm{C}$ copepod ${ }^{-1} \mathrm{~d}^{-1}$ and Metridia gerlachei 5 to $7 \mu \mathrm{g} \mathrm{C}$ copepod $\mathrm{d}^{-1} \mathrm{~d}^{-1}$, which is a daily ration of 2 to $3 \%$ and 4 to $5 \%$ body weight for $C$. propinquus and $M$. gerlachei respectively (Table 2). These values are at the lower limits to meet metabolic requirements (Huntley et al. 1991). The carnivorous feeding rates were low compared with grazing on natural phytoplankton $\left(0.3\right.$ to $\left.1.4 \mu \mathrm{g} \mathrm{chl} \mathrm{a}^{-1}\right)$ during the investigation period, which was in the range of 1.2 to $8 \%$ body weight for C. propinquus and 4 to $10.4 \%$ for M. gerlachei (Schnack-Schiel unpubl.). The daily rates of Oncaea curvata ingestion will be even lower in situ since our initial experimental concentration of $75 \times 10^{3}$ $O$. curvata females $\mathrm{m}^{-3}$ was higher than the concentrations of 2 to 50 females $\mathrm{m}^{-3}$ in the Bellingshausen Sea during summer (Metz unpubl.). During winter the concentrations will be even lower. However, it should be considered that this species was used only as an example of animal prey, and other organisms in the same size range, such as large nauplii, different copepodite stages of Oncaeidae, Oithonidae and smaller Calanoida, are probably also preyed upon.

In the eastern Weddell Sea, maximum concentrations of Oncaea spp., Oithona spp. and copepod nauplii combined (300 to 800 ind $\mathrm{m}^{-3}$ ) occurred in midwater layers during winter (August to November), while during summer/autumn, 1000 to 7500 ind. $\mathrm{m}^{-3}$ were found in the upper $100 \mathrm{~m}$ (Schnack-Schiel unpubl.). As the annual migration of Antarctic Oncaeidae and Oithonidae (Metz 1995, Schnack-Schiel unpubl.) is in a similar depth range as the migration of Calanus propinquus and Metridia gerlachei (SchnackSchiel \& Hagen 1995), the stock of Oncaeidae, and probably also Oithonidae, is a food source, in addition to phytoplankton, available to $C$. propinquus and $M$. gerlachei. This resource becomes more important during winter when phytoplankton is virtually absent in the water column. However, C. propinquus, which stays partly in the surface layer in winter (Marin 1988, Bathmann et al. 1993, Schnack-Schiel \& Hagen 1995), might also graze ice-algae on the ice undersurfaces or which are released into the water $C$. propinquus frequently had full and green guts, despite the paucity of chlorophyll in the water (Atkinson \& Shreeve 1995). $M$. gerlachei is a typical mid-water species never occurring in maximum concentrations at the surface (Hopkins \& Torres 1988, Huntley \& Escritor 1992, SchnackSchiel \& Hagen 1995) where high phytoplankton concentrations exist in summer. Therefore phytoplankton is probably not the only food resource. On the other hand, although this species lives mainly below the productive upper layers, it migrates into shallower water layers during night for feeding (Lopez \& Huntley 1995). Additionally, $M$ gerlachei appears to be able to grow on a pure phytoplankton diet (Schnack 1983a, 1985, Schnack et al. 1985b, Huntley \& Escritor 1992). This information indicates that carnivorous feeding is not vital for this species, but might be very important during winter when phytoplankton is extremely scarce. We did not observe feeding on Oncaea spp. females by juvenile $M$. gerlachei. These developmental stages occur, as the adults, in maximum abundances in midwater-layers and account for 75 and $99 \%$ of the $M$. gerlachei population in the eastern Weddell Sea during winter (Schnack-Schiel \& Hagen 1995). The lipid content of copepodite stages CIV and CV expressed as \% of dry weight was about twice as high as that of female $M$. gerlachei in October/November in the eastern Weddell Sea (Schnack-Schiel \& Hagen 1995). This could indicate that juvenile stages rely more on lipid reserves than females, although detritus and small heterotrophic microorganisms might be other sources of food. In the Ross Sea, Antarctica in summer young $M$. gerlachei guts contained tintinnids, peridian dinoflagellates and diatoms, while adult females had eaten additional metazoans, e.g. Oithona spp. and Oncaea spp. (Hopkins 1987). In winter, small flagellates, dinoflagellates and ciliates dominated the protist community in the Weddell Sea (Scharek 1991). These organisms, besides metazoans such as Oncaeidae and Oithonidae, may also contribute to the diet of calanoid copepods.

Acknowledgements. We are grateful for the support of the captain and crew of RV 'Polarstern' We thank D. Thomas for critically reading the manuscript. This is contribution no. 878 of the Alfred-Wegener-Institut fur Polar- und Meeresforschung, Bremerhaven.

\section{LITERATURE CITED}

Atkinson A (1991) Life cycles of Calanoides acutus, Calanus simillimus and Rhincalanus gigas (Copepoda: Calanoida) within the Scotia Sea. Mar Biol 109:79-91

Atkinson A (1994) Diets and feeding selectivity among the epipelagic copepod community near South Georgia in summer. Polar Biol 14:551-560

Atkinson A, Shreeve RS (1995) Response of the copepod community to a spring bloom in the Bellingshausen Sea. Deep Sea Res 42:1291-1311

Atkinson A, Ward P, Williams R, Poulet SA (1992) Feeding rates and diel vertical migration of copepods near South Georgia: comparison of shelf and oceanic sites. Mar Biol 114:49-56

Bathmann UV, Makarov RR, Spirıdonov VA, Rohardt G (1993) Winter distribution and overwintering strategies of the Antarctic copepod species Calanoides acutus, Rhincalanus gigas and Calanus propinquus (Crustacea, Calanoida) in the Weddell Sea. Polar Biol 13:333-346

Boysen-Ennen E, Hagen W. Hubold G, Piatkowski U (1991) Zooplankton biomass in the ice-covered Weddell Sea, Antarctica. Mar Biol 111:227-235

Conover RJ (1966) Feeding on large particles by Calanus hyperboreus (Kroyer). In: Barnes H (ed) Some contempo- 
rary studies in marine science. George Allen and Unwin, Ltd, London, p 187-194

Conover RJ, Huntley M (1991) Copepods in ice-covered seas - distribution, adaptations to seasonally limited food, metabolism, growth pattern and life cycle strategies in polar seas. J mar Syst 2:1-41

Corner EDS, Head RN, Kilvington CC, Marshall SM (1974) On the nutrition and metabolism of zooplankton. IX. Studjes relating to the nutrition of overwintering Calanus. J mar biol Ass UK 54:319-331

Corner EDS, Head RN, Kilvington CC. Pennycuick L (1976) On the nutrition and metabolism of zooplankton. X. Quantitative aspects of Calanus helgolandicus feeding as a carnivore. $\mathrm{J}$ mar biol Ass UK 56:345-358

Cushing DH (1955) Production and a pelagic fishery. Fishery Invest Lond, Ser 2, Vol 18, No 7

Drits AV, Pasternak AF, Kosobokova KN (1993) Feeding, metabolism and body composition of the Antarctic copepod Calanus propinquus Brady with special reference to its life cycle. Polar Biol 13:13-21

Fransz HG (1988) Vernal abundance, structure and development of epipelagic copepod populations of the eastern Weddell Sea (Antarctica). Polar Biol 9:107-114

Graeve M, Hagen W, Kattner G (1994) Herbivorous or omnivorous? On the significance of lipid compositions as trophic markers in Antarctic copepods. Deep Sea Res 41:915-924

Hagen W, Kattner G, Graeve M (1993) Calanoides acutus and Calanus propinquus, Antarctic copepods with different lipid storage modes via wax esters or triacylglycerols. Mar Ecol Prog Ser 97:135-142

Hopkins TI (1985a) The zooplankton community of Croker Passage, Antarctic Peninsula. Polar Biol 4:161-170

Hopkins TL (1985b) Food web of an Antarctic midwater ecosystem. Mar Biol 89:197-212

Hopkins TL (1987) Midwater food web in McMurdo Sound, Ross Sea, Antarctica. Mar Biol 96:93-106

Hopkins TL, Ainley DG, Torres JJ, Lancraft TM, (1993b) Trophic structure in open waters of the marginal ice zone in the Scotia-Weddell confluence region during spring (1983). Polar Biol 13:389-397

Hopkins TL, Lancraft TM, Torres JJ, Donnelly J (1993a) Community structure and trophic ecology of zooplankton in the Scotia Sea marginal ice zone in winter (1988). Deep Sea Res 40:81-105

Hopkins TL, Torres JJ (1988) The zooplankton community in the vicinity of the ice edge, western Weddell Sea, March 1986. Polar Biol 9:79-87

Hopkins TL, Torres JJ (1989) Midwater food web in the vicinity of a marginal ice zone in the western Weddell Sea. Deep Sea Res 36:543-560

Huntley ME, Escritor F (1992) Ecology of Metridia gerlachei Giesbrecht in the western Bransfield Strait, Antarctica. Deep Sea Res 39:1027-1055

Huntley ME, Karl DM, Niiler P, Holm-Hansen O (1991) Research on Antarctic Coastal Ecosystem Rates (RACER): an interdisciplinary field experiment. Deep Sea Res 38: 911-941

Landry MR (1981) Switching between herbivory and carnivory by the planktonic marine copepod Calanus pacificus. Mar Biol 65:77-82

Lopez MDG. Huntley ME (1995) Feeding and diel vertical migration cycles of Metridia gerlachei (Giesbrecht) in coastal waters of the Antarctic Peninsula. Polar Biol 15: $21-30$

Marin V (1988) Qualitative models of the life cycles of
Calanoides acutus, Calanus propinquus and Rhincalanus gigas. Polar Biol 8:439-446

Marin V, Schnack-Schiel SB (1993) The occurrence of Rhincalanus gigas, Calanoides acutus and Calanus propinquus (Copepoda: Calanoida) in late May in the area of the Antarctic Peninsula. Polar Biol 13:35-40

Metz C (1995) Seasonal variation in the distribution and abundance of Oithona and Oncaea species (Copepoda, Crustacea) in the southeastern Weddell Sea, Antarctica Polar Biol 15:187-194

Mizdalski E (1988) Weight and length data of zooplankton in the Weddell Sea in austral spring 1986 (ANT V/3). Ber Polarforsch 55:1-72

Mullin MM, Brooks ER (1967) Laboratory culture, growth rate, and feeding behavior of a planktonic marine copepod. Limnol Oceanogr 12:657-666

Paffenhöfer GA (1971) Grazing and ingestion rates of nauplii, copepodids and adults of the marine planktonic copepod Calanus finmarchicus. Mar Biol 11:286-298

Paffenhöfer GA (1988) Feeding rates and behavior of zooplankton. Bull mar Sci 43:430-445

Parsons TR, LeBrasseur RJ (1970) The availibility of food to different trophic levels in the marine food chain. In: Steele JH (ed) Marine food chains. Oliver \& Boyd, Edinburgh, p $325-343$

Parsons TR, LeBrasseur RJ, Fulton JD, Kennedy OD (1969) Production studies in the Strait of Georgia. Part II. Secondary production under the Fraser River plume, February to May, 1967. J exp mar Biol Ecol 3:39-50

Scharek R (1991) Die Entwicklung des Phytoplanktons im östlichen Weddellmeer (Antarktis) beim Übergang vom Spätwinter zum Frühjahr. Ber Polarforsch 94:1-195

Schnack SB (1983a) On the feeding of copepods on Thalasslosira partheneia from the Northwest African upwelling area. Mar Ecol Prog Ser 11:49-53

Schnack SB (1983b) Feeding of two Antarctic copepod species (Calanus propinquus and Metridia gerlachei) on a mixture of centric diatoms. Polar Biol 2:63-68

Schnack SB (1985) Feeding by Euphausia superba and copepod species in response to varying concentrations of phytoplankton. In: Siegfried WR, Condy PR, Laws RM (eds) Antarctic nutrient cycles and food webs. SpringerVerlag, Berlin, p 311-323

Schnack SB, Marschall S, Mizdalski E (1985a) On the distribution of copepods and larvae of Euphausia superba in Antarctic waters during February 1982. Meeresforsch 30: $251-263$

Schnack SB, Smetacek V, von Bodungen B, Stegmann P (1985b) Utilization of phytoplankton by copepods in Antarctic waters during spring. In: Gray JS, Christiansen ME (eds) Marine biology of polar regions and effects of stress on marine organisms. Wiley \& Sons, Chichester, $p$ $65-81$

Schnack-Schiel SB, Hagen W (1995) Life cycle strategies of Calanoides acutus, Calanus propinquus and Metridia gerlachei (Copepoda: Calanoida) in the eastern Weddell Sea, Antarctica. ICES J mar Sci 52:541-548

Schnack-Schiel SB, Hagen W, Mizdalski E (1991) Seasonal comparison of Calanoides acutus and Calanus propinquus (Copepoda: Calanoida) in the southeastern Weddell Sea, Antarctica. Mar Ecol Prog Ser 70:17-27

Smith SL, Schnack-Schiel SB (1990) Polar zooplankton. In: Smith WO Jr (ed) Polar oceanography, Part B, Chemistry, biology, and geology. Academic Press, New York, p $527-598$

Manuscript first received: March 6, 1995

Revised version accepted: June 19, 1995 